\title{
Activation of short-chain ketones and isopropanol in sulfate-reducing bacteria
}

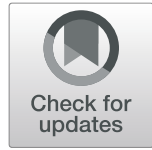

Jasmin Frey ${ }^{1}$, Sophie Kaßner ${ }^{1}$, Dieter Spiteller ${ }^{1}$, Mario Mergelsberg ${ }^{2}$, Matthias Boll ${ }^{2}$, David Schleheck ${ }^{1}$ and Bernhard Schink $^{1 *}$

\begin{abstract}
Background: Degradation of acetone by aerobic and nitrate-reducing bacteria can proceed via carboxylation to acetoacetate and subsequent thiolytic cleavage to two acetyl residues. A different strategy was identified in the sulfate-reducing bacterium Desulfococcus biacutus that involves formylation of acetone to 2-hydroxyisobutyryl-CoA.

Results: Utilization of short-chain ketones (acetone, butanone, 2-pentanone and 3-pentanone) and isopropanol by the sulfate reducer Desulfosarcina cetonica was investigated by differential proteome analyses and enzyme assays. Two-dimensional protein gel electrophoresis indicated that D. cetonica during growth with acetone expresses enzymes homologous to those described for Desulfococcus biacutus: a thiamine diphosphate (TDP)-requiring enzyme, two subunits of a $\mathrm{B}_{12}$-dependent mutase, and a $\mathrm{NAD}^{+}$-dependent dehydrogenase. Total proteomics of cell-free extracts confirmed these results and identified several additional ketone-inducible proteins. Acetone is activated, most likely mediated by the TDP-dependent enzyme, to a branched-chain CoA-ester, 2-hydroxyisobutyrylCoA. This compound is linearized to 3-hydroxybutyryl-CoA by a coenzyme $B_{12}$-dependent mutase followed by oxidation to acetoacetyl-CoA by a dehydrogenase. Proteomic analysis of isopropanol- and butanone-grown cells revealed the expression of a set of enzymes identical to that expressed during growth with acetone. Enzyme assays with cell-free extract of isopropanol- and butanone-grown cells support a $\mathrm{B}_{12}$-dependent isomerization. After growth with 2-pentanone or 3-pentanone, similar protein patterns were observed in cell-free extracts as those found after growth with acetone.
\end{abstract}

Conclusions: According to these results, butanone and isopropanol, as well as the two pentanone isomers, are degraded by the same enzymes that are used also in acetone degradation. Our results indicate that the degradation of several short-chain ketones appears to be initiated by TDP-dependent formylation in sulfatereducing bacteria.

Keywords: Anaerobic acetone degradation, Ketone degradation, Pentanone, Sulfate reduction, 2-hydroxyisobutyrylCoA, Thiamine diphosphate, Adenosylcobalamin

\footnotetext{
* Correspondence: bernhard.schink@uni-konstanz.de

${ }^{1}$ Department of Biology, University of Konstanz, 78457 Constance, Germany

Full list of author information is available at the end of the article
}

(c) The Author(s). 2021 Open Access This article is licensed under a Creative Commons Attribution 4.0 International License, which permits use, sharing, adaptation, distribution and reproduction in any medium or format, as long as you give appropriate credit to the original author(s) and the source, provide a link to the Creative Commons licence, and indicate if changes were made. The images or other third party material in this article are included in the article's Creative Commons licence, unless indicated otherwise in a credit line to the material. If material is not included in the article's Creative Commons licence and your intended use is not permitted by statutory regulation or exceeds the permitted use, you will need to obtain permission directly from the copyright holder. To view a copy of this licence, visit http://creativecommons.org/licenses/by/4.0/ The Creative Commons Public Domain Dedication waiver (http://creativecommons.org/publicdomain/zero/1.0/) applies to the data made available in this article, unless otherwise stated in a credit line to the data. 


\section{Background}

Short-chain ketones are used in industry as solvents and as precursors for chemical syntheses. Acetone is produced by a wide range of industrial processes, such as the co-production with phenol in the so-called cumene process. It is also produced by fermenting bacteria such as Clostridium spp., or in higher animals and humans during ketosis [1, 2]. Isopropanol and butanone are commonly used as solvents in industrial processes and are also side products of microbial degradation processes in soils. Acetone, isopropanol, butanone and 2-pentanone belong to the ten most abundant volatile organic compounds (VOCs) in agricultural soils [3]. Next to acetone and butanone, 3-pentanone, also known as diethyl ketone, is a common odor component of landfills [4]. They are released into the environment in considerable amounts, rendering their microbial degradation a relevant component of the biogeochemical carbon cycle. Acetone (and other ketones) are present in the human body in blood, urine and exhaled air (ketosis), but they are also present in the human intestinal system as a result of microbial fermentation: ketones are the second largest class of volatile organic compounds in human feces $[5,6]$. Therefore, degradation of ketones might be relevant also in the metabolism of human gut microbiota. Other sources of acetone and butanone are the emission from plant material during photochemical processes $[7,8]$.

Several metabolic routes are known for acetone degradation by microorganisms. Aerobic microbes may initiate acetone degradation by activation through a Baeyer-Villiger monooxygenase to methyl acetate ester, by terminal hydroxylation to acetol (hydroxyacetone), or by carboxylation to acetoacetate $[6,9,10]$. Nitrate-reducing and phototrophic bacteria activate acetone by carboxylation which is coupled to the consumption of two or more ATP equivalents per molecule of acetone [11-15]. While such an energyexpensive activation reaction is possible for nitratereducing and phototrophic bacteria, it is not feasible for sulfate-reducing bacteria due to their much smaller energy budget [11, 16-18].

Sulfate reducers play important roles in the environment, especially in marine sediments and in technical settings such as the oil industry or wastewater technology [19]. They are also active in the digestive system of animals and humans both in healthy individuals and in persons afflicted with diseases like ulcerative colitis $[20,21]$. They also appear to be involved in or associated with chronic inflammatory bowel diseases (IBD) in humans caused most likely by release of highly toxic and reactive hydrogen sulfide, e.g., through $\mathrm{H}_{2} \mathrm{~S}$-mediated inhibition of butyrate oxidation in colonocytes [22-24].
Thus far, two sulfate-reducing bacteria (SRB) have been described that are capable of utilizing acetone and butanone as electron donor and carbon source: Desulfococcus biacutus strain KMRActS (DSM 5651) and Desulfosarcina cetonica strain 480 (DSM 7267) [16, 25-27]. In D. biacutus acetone carboxylase activity was not detectable in cell-free extracts, and the respective candidate genes not found in the genome either. Moreover, no acetoacetate-activating enzyme (e.g. acetyl-CoA:acetoacetate CoA transferase or acetoacetate CoA ligase) was measurable $[16,26,28]$. Further experiments led to the assumption that carbon monoxide may be used as cosubstrate leading to a reactive aldehyde species that is subsequently transformed to acetoacetyl-CoA [29]. Genomic and proteomic studies revealed a gene cluster in $D$. biacutus that is strongly induced during acetone utilization: the cluster encodes a thiamine diphosphate (TDP)-dependent enzyme, a $B_{12}$-dependent isomerase and a $\mathrm{NAD}^{+}$-dependent dehydrogenase [28]. Results from recent studies suggested that the three (potential) enzymes catalyze the following reaction sequence [30]: (i) formylation of acetone to the branched-chain $\mathrm{CoA}$ ester 2-hydroxyisobutyryl-CoA, most likely mediated by the TDP-dependent enzyme, (ii) conversion to 3hydroxybutyryl-CoA by the $\mathrm{B}_{12}$-dependent mutase, and (iii) oxidation to acetoacetyl-CoA by a dehydrogenase. While the enzyme identities and intermediates for the last two reactions were confirmed in cell-free extracts by mass spectrometry and by heterologously produced enzymes [30], the (predicted) TDP-dependent enzyme reaction remained experimentally inaccessible so far. $D$. cetonica harbors genes that are homologous to those found in D. biacutus. Therefore, it appears plausible that both bacteria, and probably more sulfate-reducing bacteria, use the same metabolic strategy for acetone degradation [30].

In the present paper, we describe acetone degradation in $D$. cetonica in order to identify similarities and/or differences to that studied previously in $D$. biacutus by differential proteomics, enzyme assays, and CoA ester metabolite analyses. In addition, degradation of butanone (2-methyl ethyl ketone), 2-pentanone, 3pentanone, and isopropanol (2-propanol) by D. cetonica was examined. In this work, also the first description of pentanone degradation by a sulfate reducer is presented on the basis of proteomic data.

\section{Methods}

\section{Chemicals}

Chemicals were purchased from Sigma-Aldrich (Germany), Apollo Scientific (UK), AppliChem (Germany) or Carl Roth GmbH (Germany). The CoA esters were synthesized using the acyl thiophenyl esters as precursors as described earlier [30]. 


\section{Bacterial growth conditions}

Desulfosarcina cetonica strain 480 was cultivated in $\mathrm{N}_{2}$ / $\mathrm{CO}_{2}$ (80\%/20\%)-flushed, butyl rubber-stoppered bottles containing sulfide-reduced, bicarbonate-buffered medium [25]. The medium was supplemented with 10 $\mathrm{mM}$ (or $20 \mathrm{mM}$ in case of pentanones) $\mathrm{Na}_{2} \mathrm{SO}_{4}$ as electron acceptor and $5 \mathrm{mM}$ carbon source (acetone, butyrate, isopropanol, butanone, 2-pentanone, and 3pentanone). Cultures were incubated at $30^{\circ} \mathrm{C}$ in the dark.

\section{Preparation of cell-free extracts (CFE)}

Cells of $D$. cetonica were harvested by centrifugation $\left(8200 \times g, 30 \mathrm{~min}, 4{ }^{\circ} \mathrm{C}\right)$ and washed twice with Tris- $\mathrm{HCl}$ buffer (20 mM, pH 7.2). The cell pellet was resuspended in Tris- $\mathrm{HCl}$ buffer $(20 \mathrm{mM}, \mathrm{pH} 7.2)$ supplemented with $0.5 \mathrm{mg}$ DNase $\mathrm{mL}^{-1}$ and $10 \mu \mathrm{L} \mathrm{mL}^{-1}$ of Halt ${ }^{\mathrm{Tw}}$ Protease Inhibitor Cocktail (with EDTA; Thermo Scientific). Cells were disrupted by three to five passages through a cooled French pressure cell at $140 \mathrm{MPa}$. Cell debris was removed by centrifugation $\left(27,000 \times g, 30 \mathrm{~min}, 4{ }^{\circ} \mathrm{C}\right)$ to produce cell-free extract (CFE). Membrane fragments were separated by ultracentrifugation $(50,000 \times g, 60 \mathrm{~min}$, $4{ }^{\circ} \mathrm{C}$ ); the supernatant was termed soluble protein fraction. Membrane fragments were washed once with buffer (the remaining supernatant was termed the wash fraction) and resuspended in the same buffer.

Two-dimensional polyacrylamide gel electrophoresis (2DPAGE) and proteome analysis

2D-PAGE of soluble proteins was performed using a BioRad Ready Strip IPG/Protean II system. The soluble protein fraction was desalted by Illustra NAP-25 columns (GE Healthcare, Germany) and each sample of 4 mg total protein was precipitated overnight at $-20^{\circ} \mathrm{C}$ by addition of 4 volumes of ice-cold acetone. Precipitated protein was collected by centrifugation $(10,000 \times g, 10$ $\mathrm{min}, 4^{\circ} \mathrm{C}$ ) and air-dried at room temperature. The dried protein pellet was solubilized in rehydration buffer $(350 \mu \mathrm{L})$ and loaded onto an isoelectric focusing (IEF) strip (BioRad IPG strips, $17 \mathrm{~cm}, \mathrm{pH} 4-7$ ) [31]. The isoelectric focusing program involved a voltage ramp (rapid) to a maximal voltage of $10,000 \mathrm{~V}$ for at least $3 \mathrm{~h}$ and a total focusing of 60,000 Volt-hours (Vh). Strips were equilibrated in SDS equilibration buffers I and II (with DTT and iodoacetamide, respectively) as described earlier [28] and placed onto a 12\% SDS-PAGE gel. Gels were stained by colloidal Coomassie staining with (final concentrations) $2 \% \quad \mathrm{H}_{3} \mathrm{PO}_{4}, \quad 10 \%$ $\left(\mathrm{NH}_{4}\right)_{2} \mathrm{SO}_{4}, 20 \%$ methanol, and $0.08 \%(\mathrm{w} / \mathrm{v})$ Coomassie Brilliant Blue R-250 [32].

Protein spots of interest were excised from the gels and analyzed by peptide fingerprinting-mass spectrometry by the Proteomics Facility of the University of
Konstanz [28]. For total proteomic analysis of cell-free extracts (CFE) from cells grown with the different substrates (acetone, butyrate, isopropanol or butanone, respectively), CFEs were analyzed directly with highresolution peptide fingerprinting-mass spectrometry (LTQ-Orbitrap, Thermo Fisher) by the Proteomics Facility of the University of Konstanz [33].

\section{Enzyme assays}

Activities of key enzymes of acetone degradation were tested by discontinuous assays analyzed by HPLC. All enzyme assays were performed under strictly anoxic conditions $\left(\mathrm{N}_{2}\right.$-flushed 4-ml glass vials sealed with butyl rubber stoppers) in $25 \mathrm{mM}$ MOPS buffer, $\mathrm{pH} 7.2$, (mutase) containing $1 \mathrm{gl}^{-1} \mathrm{NaCl}, 0.6 \mathrm{gl}^{-1} \mathrm{MgCl}_{2} \times 6 \mathrm{H}_{2} \mathrm{O}$ and $3 \mathrm{mM}$ DTT. $\mathrm{B}_{12}$-dependent reaction mixes contained additional $50 \mu \mathrm{M}$ adenosylcobalamin and were incubated in the dark at $30^{\circ} \mathrm{C}$. Reactions were started by addition of cell-free extract and were followed discontinuously by HPLC-UV or HPLC-MS measurements. Substrate addition and sampling $(150-200 \mu \mathrm{L}$ per sample) under anoxic conditions was performed with gastight syringes (Hamilton AG, Switzerland). Samples were mixed thoroughly with dichloromethane to stop the reaction and remove protein. After centrifugation $(16,000$ $\mathrm{x} g, 5 \mathrm{~min}$, RT $\left(20-23^{\circ} \mathrm{C}\right)$ ), the aqueous phase was used for analysis by HPLC or LC-MS.

All photometric assays were carried out in MOPS buffer under strictly anoxic conditions as described above. 3-hydroxybutyryl-CoA dehydrogenase was measured photometrically as 3-hydroxybutyryl-CoAdependent $\mathrm{NAD}^{+}$reduction at $340 \mathrm{~nm}$. A coupled photometric assay for measurement of the $\mathrm{B}_{12^{-}}$ dependent isomerization of 2-hydroxyisobutyryl-CoA to 3-hydroxybutyryl-CoA was performed in a similar setup containing 2-hydroxyisobutyryl-CoA instead of 3hydroxybutyryl-CoA. The subsequent oxidation of the isomerization product 3-hydroxybutyryl-CoA was measured photometrically as described above.

\section{High pressure liquid chromatography (HPLC) and HPLC- mass spectrometry (MS) measurements}

CoA esters were analyzed by HPLC using a Kinetex PFP column ( $5 \mathrm{~mm}, 100 \mathrm{~A}^{\circ}, 25034.6 \mathrm{~mm}$; Phenomenex, USA) on a Shimadzu Prominence system with PDA detector (SPD-M20A). The temperature was set to $40^{\circ} \mathrm{C}$ and a flow rate of $0.75 \mathrm{~mL} \mathrm{~min}^{-1}$ was used. The injection volume was $5 \mu \mathrm{L} .100 \mathrm{mM}$ ammonium acetate (eluent B) and acetonitrile (eluent A) were used as eluents. The separation started with $5 \%$ eluent A for 15 min followed by a gradient step $(1 \mathrm{~min})$ up to $80 \%$ eluent $\mathrm{A}$, holding $80 \%$ eluent $\mathrm{A}$ for $1 \mathrm{~min}$, an additional gradient $(1 \mathrm{~min})$ back to $5 \%$ eluent $\mathrm{A}$ and a re-equilibration with $5 \%$ eluent A for $8 \mathrm{~min}$. For HPLC-electrospray ionization 
(ESI)-MS/MS, an Agilent 1100 HPLC system and the Kinetex PFP column (see above) connected to an LCQ ion trap mass spectrometer (Thermo Fisher Scientific) was used [30]. The injection volume was $50 \mu \mathrm{L}$. The column was run isocratically with $95 \% 100 \mathrm{mM}$ ammonium acetate and $5 \%$ acetonitrile for $10 \mathrm{~min}$ at a flow rate of $0.75 \mathrm{ml} / \mathrm{min}$ and a temperature of $40^{\circ} \mathrm{C}$.

\section{CoA ester extraction from intact cells and UPLC-MS analysis}

For analysis of the CoA ester pool in growing cells, $D$. cetonica was grown with acetone or butyrate as sole carbon source. Cells were harvested in the midexponential growth phase, lysed on ice with an ice-cold solution containing $0.1 \mathrm{M}$ formic acid and $80 \%$ acetonitrile, and subsequently lyophilized [34]. Lyophilized samples were dissolved in $200 \mu \mathrm{L} 10 \mathrm{mM}$ ammonium acetate and centrifuged two times. The supernatant was used for UPLC-MS measurements.

Samples were analyzed with a Waters Acquity I-Class UPLC coupled to a Waters Synapt G2-Si HDMS ESIQTOF mass spectrometer. UPLC separation was conducted using a Waters Acquity UPLC HSS T3 column $(2.1 \times 100 \mathrm{~mm})$ with a 20 min linear gradient of $2 \%$ acetonitrile to $40 \%$ acetonitrile in $10 \mathrm{mM}$ ammonium acetate buffer at $0.35 \mathrm{ml} / \mathrm{min}$. The mass spectrometer was operated in positive ion mode with a capillary voltage of $3.0 \mathrm{kV}$, a source temperature of $150^{\circ} \mathrm{C}$, a desolvation temperature of $450^{\circ} \mathrm{C}$ and desolvation gas flow of $1000 \mathrm{~L} / \mathrm{h}$. Theoretical $\mathrm{m} / \mathrm{z}$ values were calculated and data were evaluated with Waters MassLynx V4.1 SCN916.

\section{Results and discussion}

\section{General properties of $D$. cetonica}

Desulfosarcina cetonica is next to Desulfococcus biacutus the only described acetone- and butanone-degrading sulfate-reducing bacterium described so far. It was isolated from stratal waters of Apsheron peninsula, Lokbatanskii deposit in Azerbaijan. D. biacutus was isolated from anoxic sludge of a sewage plant in Marburg, Germany $[16,27]$.

In this study, proteome data were analyzed for all major metabolic pathways of $D$. cetonica. A full set of

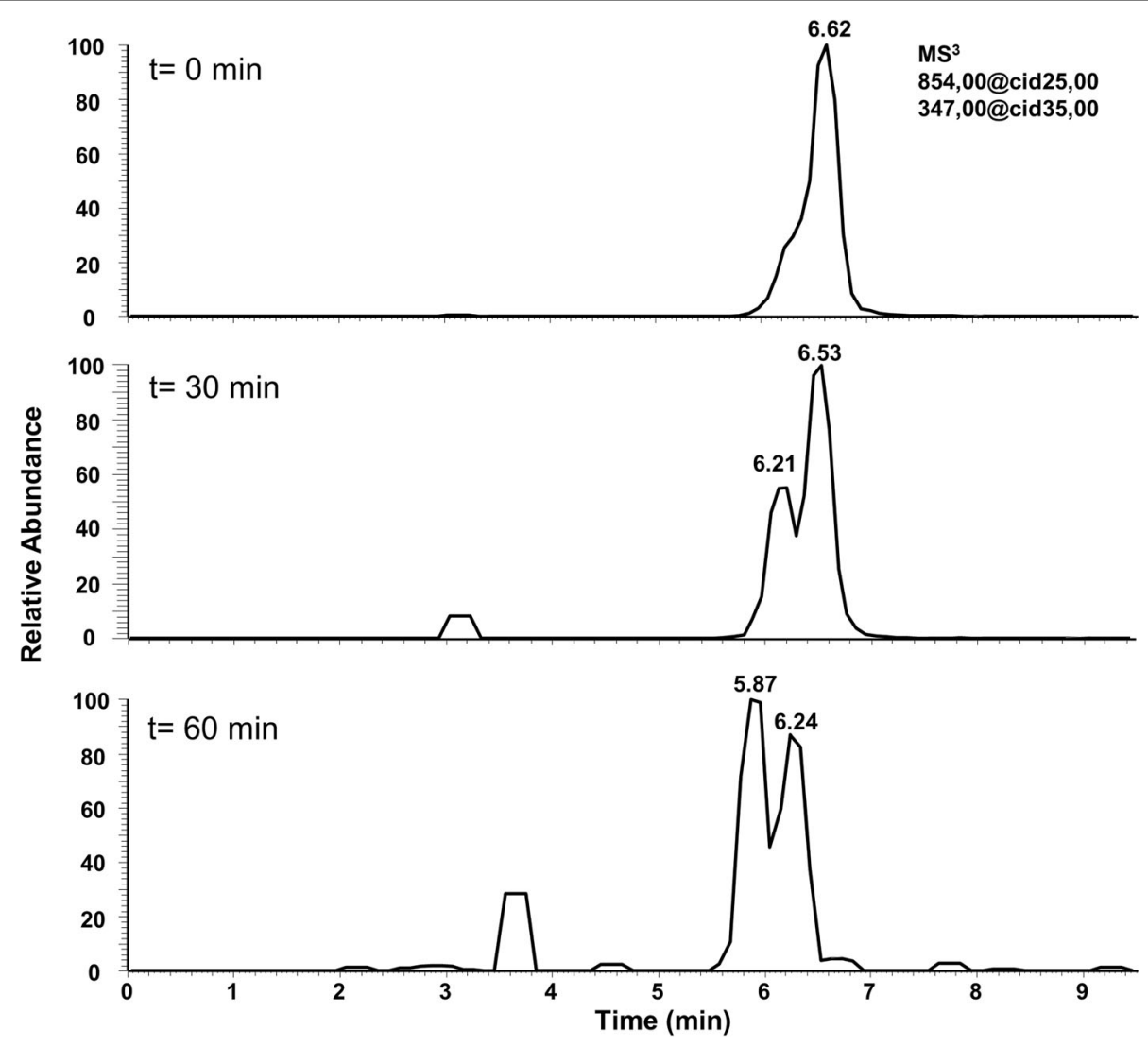

Fig. 1 Representative HPLC-MS chromatograms of an in vitro enzyme assay of the $B_{12}$-dependent 2-hydroxyisobutyryl-CoA mutase reaction. Time course measurement of the reaction showing formation of 3-hydroxybutyryl-CoA (peak eluting between 5.87 and 6.21 min), concomitant with disappearance of 2-hydroxyisobutyryl-CoA (peak eluting between 6.24 and $6.62 \mathrm{~min}$ ). The product 3-hydroxybutyryl-CoA eluted before the substrate 2-hydroxyisobutyryl-CoA 
enzymes was identified that allows dissimilatory sulfate reduction and complete oxidation of acetyl residues via the reversed Wood-Ljungdahl pathway. Furthermore, most enzymes of the citric acid cycle (except for malate dehydrogenase and aconitase) were detected by total proteomics.

\section{Inducible 2-hydroxyisobutyryl-CoA mutase and NAD ${ }^{+}$} dependent 3-hydroxybutyryl-CoA dehydrogenase activity in cell-free extracts of acetone-grown cells of $D$. cetonica Cell-free extracts (CFE) of acetone-grown cells of $D$. cetonica were analyzed for two key enzyme activities of acetone metabolism observed previously in D. biacutus. 2-hydroxyisobutyryl-CoA mutase activity was tested in reactions containing CFE, 2-hydroxyisobutyryl-CoA and $\mathrm{B}_{12}$ (adenosylcobalamin) using HPLC fragmentationmass spectrometry. The $B_{12}$ - dependent isomerization of 2-hydroxyisobutyryl-CoA to 3-hydroxybutyryl-CoA was detectable in extracts of cells grown with acetone, but not with butyrate (Fig. 1), suggesting that the synthesis of the enzyme is induced during growth with acetone. Further, the activity of a $\mathrm{NAD}^{+}$-dependent 3hydroxybutyryl-CoA dehydrogenase was detected in CFE of acetone-grown cells $\left(449.6 \pm 44.2 \mathrm{mU} \mathrm{mg}^{-1}\right)$; the activity in butyrate-grown cells was lower $(222.9 \pm 66.4$ $\mathrm{mU} \mathrm{mg}^{-1}$ protein). When the $\mathrm{B}_{12}$-dependent isomerization of 2-hydroxyisobutyryl-CoA was coupled to the $\mathrm{NAD}^{+}$-dependent oxidation of 3-hydroxybutyryl-CoA to acetoacetyl-CoA by addition of 2-hydroxyisobutyryl$\mathrm{CoA}, \mathrm{B}_{12}$ and $\mathrm{NAD}^{+}$, the activity was $1.0 \pm 0.2 \mathrm{mU}$ $\mathrm{mg}^{-1}$ protein in CFE of acetone-grown cells, but no such activity was found in CFE of butyrate-grown cells. This finding agrees with previous studies with $D$. biacutus that was also reported to isomerize 2-hydroxyisobutyrylCoA to 3-hydroxybutyryl-CoA using a $\mathrm{B}_{12}$-dependent mutase followed by dehydrogenation to acetoacetyl-CoA (initially annotated as a 3-oxoacyl-[acyl carrier protein (ACP)] reductase) $[28,30]$.

Attempts to demonstrate the predicted TDPdependent enzymatic conversion of acetone to 2hydroxyisobutyryl-CoA (Fig. 2A) were unsuccessful with CFE of D. cetonica, as previously reported with CFE of D. biacutus: reaction of $\mathrm{CFE} /$ acetone with the potential C1-cosubstrates $\mathrm{CO}, \mathrm{CO}_{2}$, formate, formaldehyde, formyl-CoA or oxalyl-CoA as formyl donor with or without addition of TDP, ATP, FAD, FMN, tetrahydrofolate, $\mathrm{NAD}^{+}$and/or $\mathrm{NADH}$ as cofactors (see also Material and methods) did not show any formation of 2hydroxybutyryl-CoA. Therefore, the nature of the formylating $\mathrm{C} 1$ unit remains elusive. It is likely that a C1-intermediate of the Wood-Ljungdahl pathway may be used as co-substrates for acetone activation. In former studies with $D$. biacutus, a co-localization of the TDP-dependent enzyme with membrane proteins was proposed [28] but there is no indication for a functional association with the membrane so far.

\section{Detection of 2-hydroxyisobutyryl-CoA as a metabolite}

Freshly harvested, freeze-dried cells of $D$. cetonica grown with acetone were examined for CoA metabolites by HPLC-MS (see Material and methods). Comparison of acetone- and butyrate-grown cells indicated the presence of 2-hydroxyisobutyryl-CoA in acetone-grown cells at about ten-fold higher abundance than in butyrate-grown cells (see Supporting information Fig. S1), thus supporting the proposed pathway (Fig. 2A). However, formyl-

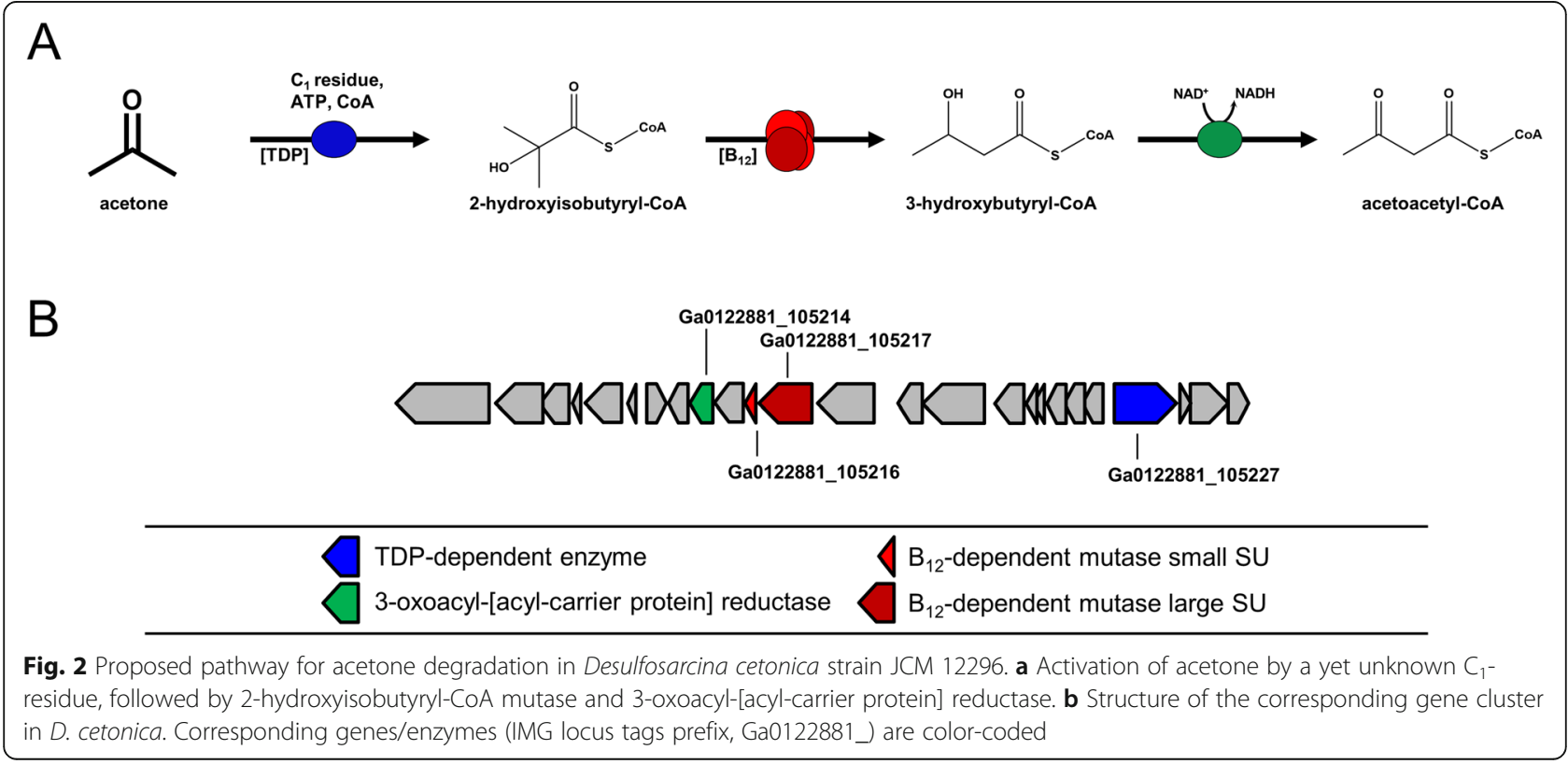



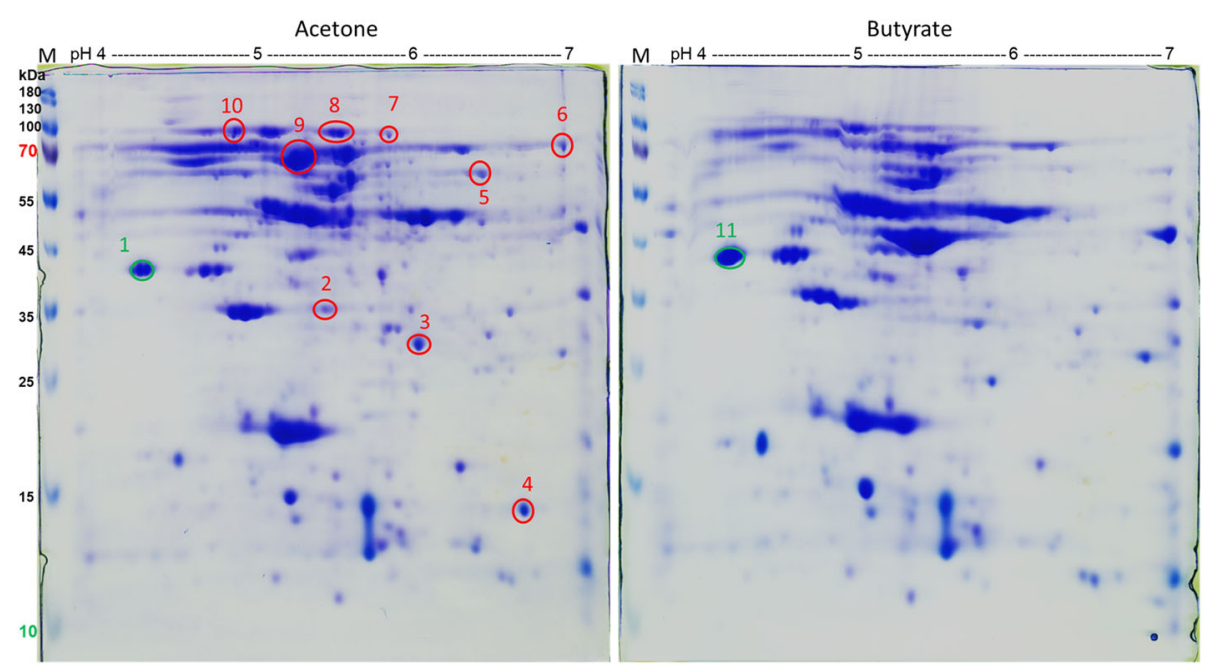

Fig. 3 2D PAGE analysis of soluble proteins obtained from acetone- and butyrate-grown cells of D. cetonica. Red-labeled spots are acetoneinduced, green-labeled spots were of similar size in both samples. Spots were excised and analyzed by peptide mass fingerprinting (for results see Table 1)

CoA as a potential formyl donor for the predicted TDPdependent conversion of acetone to 2hydroxyisobutyryl-CoA was not detectable by HPLC-MS in the cells under these conditions. No further prominent CoA-intermediate was found exclusively in acetonegrown cells during analyses of ion chromatograms with CoA ester-specific fragmentation patterns.

\section{Proteomic identification of acetone-inducible enzymes in D. cetonica}

Soluble protein fraction of acetone- and butyrate-grown cells were compared by two-dimensional protein electrophoresis (2D PAGE). All protein spots with higher abundance in acetone-grown cells (Fig. 3) were excised, and the tryptic peptides obtained were analyzed by MS. The proteins identified are listed in Table 1 . Nine protein spots (spots 2-10, Fig. 3) were either exclusively present or were more abundant in the soluble protein fraction of acetone-grown cells. Two further protein spots produced at almost equal abundance under both growth conditions were excised as controls to ensure correct localization in the gel and exclusion of carry-over of other proteins (spots 1 and 11, Fig. 3).

Spots 3, 4, 6 and 9 were clearly higher abundant in cells grown with acetone (Fig. 3) and are annotated as 3oxoacyl-[acyl-carrier protein] reductase (IMG locus tag: Ga0122881_105,214; in the following the tag prefix Ga0122881_ is omitted), methylmalonyl-CoA mutase

Table 1 Identification of proteins after 2D-PAGE analysis of D. cetonica grown with acetone/sulfate vs. butyrate/sulfate. Spots 2-10 were specifically induced after growth with acetone. Proteins of the proposed acetone degradation cluster are marked in bold. Spots 1 and 11 served as control spot and were found to be identical in both conditions

\begin{tabular}{|c|c|c|c|c|c|}
\hline Spot ID & IMG locus tag & Annotation & Score & MW & calc. pl \\
\hline 1 & Ga0122881_14251 & electron transfer flavoprotein beta subunit & 2029 & 26.6 & 4.35 \\
\hline 2 & Ga0122881_108331 & hypothetical protein & 3373 & 19.3 & 5.73 \\
\hline 3 & Ga0122881_105,214 & 3-oxoacyl-[acyl-carrier protein] reductase & 23,994 & 28.0 & 5.72 \\
\hline 4 & Ga0122881_105,216 & methylmalonyl-CoA mutase, C-terminal domain & 15,935 & 14.5 & 6.54 \\
\hline 5 & Ga0122881_103346 & Formate-tetrahydrofolate ligase & 10,064 & 53.4 & 6.55 \\
\hline 6 & Ga0122881_105,227 & Acetolactate synthase large subunit & 1857 & 77.6 & 6.62 \\
\hline 7 & Ga0122881_10451 & pyruvate carboxylase subunit B & 11,267 & 63.7 & 5.73 \\
\hline 8 & Ga0122881_10843 & acetyl-CoA decarbonylase/synthase beta subunit & 20,590 & 81.0 & 5.35 \\
\hline 9 & Ga0122881_105,217 & methylmalonyl-CoA mutase & 14,980 & 64.7 & 5.11 \\
\hline \multirow[t]{2}{*}{10} & Ga0122881_103051 & iron complex outermembrane receptor protein & 9818 & 73.2 & 4.96 \\
\hline & Ga0122881_11832 & outer membrane receptor for ferrienterochelin and colicins & 7161 & 74.0 & 5.00 \\
\hline 11 & Ga0122881_14251 & electron transfer flavoprotein beta subunit & 13,308 & 26.6 & 4.35 \\
\hline
\end{tabular}


(C-terminal domain) (105216), TDP-dependent acetolactate synthase large subunit (105227), and methylmalonyl-CoA mutase (105217) (Table 1), respectively. The genes for these proteins are located in the same gene cluster (Fig. 2B) and most likely the two proteins annotated as methylmalonyl-CoA mutase $(105,216$, $105,217)$ are two different assingments of one enzyme, as described for the homologous proteins in D. biacutus [30]. In D. biacutus, homologous proteins were observed to be acetone-induced, and the encoding genes are also located in one gene cluster [28]. The acetolactate synthase (105227) has high similarities $(87.7 \%$ identity at the amino acid level using IMG Genome BLASTP) to an acetone-induced TDP-dependent enzyme of D. biacutus. Also the two subunits of $\mathrm{B}_{12}$-dependent methylmalonylCoA mutase $(105,216,105,217)$ showed high similarities (85.6 and $85.5 \%$, respectively amino acid sequence identity) to the acetone-induced homologs of D. biacutus. The 3-oxoacyl-[acyl-carrier protein] reductase of D. cetonica exhibited $82.2 \%$ sequence identity at the amino acid level to an acetone-induced enzyme in D. biacutus. Furthermore, it was demonstrated that the acetone-specific enzyme initially annotated as 3-oxoacyl-[acyl-carrier protein] reductase of $D$. biacutus oxidizes 3-hydroxybutyrylCoA to acetoacetyl-CoA [30].
Spots $2,5,7,8$, and 10 were identified as a hypothetical protein, formate-tetrahydrofolate ligase, pyruvate carboxylase subunit B, acetyl-CoA decarbonylase/synthase beta subunit and iron complex outer membrane receptor protein / outer membrane receptor for ferrienterochelin and colicins. However, these five proteins appeared to be constitutively expressed under both growth conditions.

In summary, these findings, as well as the identification of 2-hydroxyisobutyryl-CoA in extracts of acetonegrown cells in the metabolomics assay strongly suggest that acetone is degraded in $D$. cetonica through the same pathway as proposed for D. biacutus [30].

\section{Proteomic identification of inducible proteins in $D$.} cetonica during growth with isopropanol and butanone We examined the expression patterns of proteins in CFE of $D$. cetonica after growth with four different electron donors, acetone, butanone, isopropanol, and butyrate (control), by total proteomic analysis without preceding 2D-PAGE separation. For these analyses, cultures had been transferred at least 10 times with the respective substrate prior to analysis to ensure adaptation. The data obtained confirmed the proteins that were identified by 2D-PAGE. Several proteins with higher abundance in

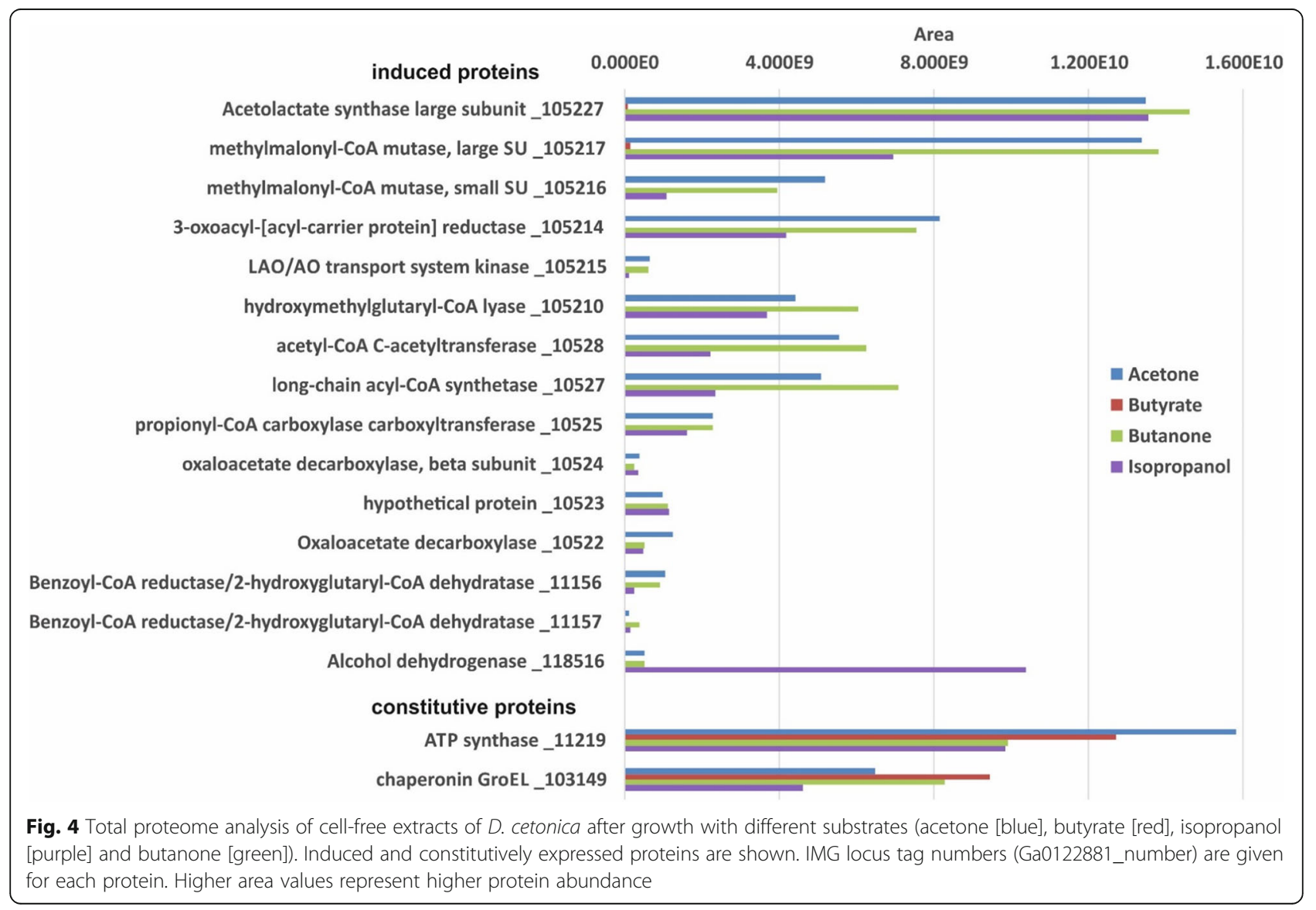


cells grown with acetone vs butyrate were identified (Fig. 4). A TDP-dependent protein annotated as acetolactate synthase (105227) was highly induced. In addition, the small and the large subunit $(105,216,105$, 217) of a $B_{12}$-dependent isomerase acting on CoA esters (annotated as methylmalonyl-CoA mutase) and a 3oxoacyl-[acyl-carrier protein] reductase (105214) were more abundant in acetone-grown cells.

In addition, several proteins abundant in acetone-grown cells were identified that escaped detection during 2DPAGE and were annotated as: hydroxymethylglutaryl-CoA lyase (105210), acetyl-CoA C-acetyltransferase (10528), long-chain acyl-CoA synthetase (10527), propionyl-CoA carboxylase carboxyltransferase subunit (10525), oxaloacetate decarboxylase beta subunit (10524), a hypothetical protein (10523), oxaloacetate decarboxylase gamma chain (10522), and two subunits of a benzoyl-CoA reductase/2hydroxyglutaryl-CoA dehydratase $(11,156,11,157)$. Many of these proteins were found to be acetone-inducible also in D. biacutus [28].

All these acetone-specific (compared to butyrate) proteins were found also in CFE of butanone- and of isopropanol-grown cells. With the exception of the two benzoyl-CoA reductase/2-hydroxyglutaryl-CoA dehydratase subunits, all other genes of the respective acetoneinduced proteins are located in one gene cluster (see Fig. $\mathrm{S} 2$ in supporting information). Additionally, a LAO/AO transport system kinase (105215) related to ArgK (MeaB) was found which may serve as a stabilizing $G$ protein for the $B_{12}$-dependent enzyme [35]. Interestingly, the genes of these six induced proteins (10522-10,528) are clustered together in one gene cluster in which also genes coding for the TDP-dependent enzyme, the two subunits of the $\mathrm{B}_{12}$-dependent mutase and the 3oxoacyl-(ACP) reductase described above are located. This strongly implies that these enzymes are involved in the degradation of acetone, isopropanol, and butanone. One might speculate that these enzymes are needed for production of another precursor molecule (e.g. formylCoA) which is used for acetone activation. Moreover, an alcohol dehydrogenase (118516) was nearly 20-fold higher abundant during growth with isopropanol than in acetone- or butanone-grown cells, and was not detected in extracts of butyrate-grown cells. Thus, this enzyme most likely catalyzes the dehydrogenation of isopropanol to acetone, but is encoded in a gene cluster different from that of the genes involved in acetone degradation.

The main difference between $D$. biacutus and $D$. cetonica is that the latter does not contain a homologue of the acetone-inducible threonine dehydrogenase (DebiaDRAFT_04514), and no homologous gene of the respective protein was found in the genome. In an earlier study, this dehydrogenase was proposed to have a detoxifying function, as it utilizes a broad variety of shortchain alcohols, aldehydes, and ketones [36]. One may speculate that lack of this protein could explain the measured difference in growth yields (for $D$. cetonica only around $1 / 3$ compared to $D$. biacutus) between $D$. biacutus and $D$. cetonica growing with the same substrate $[16,25,26]$.

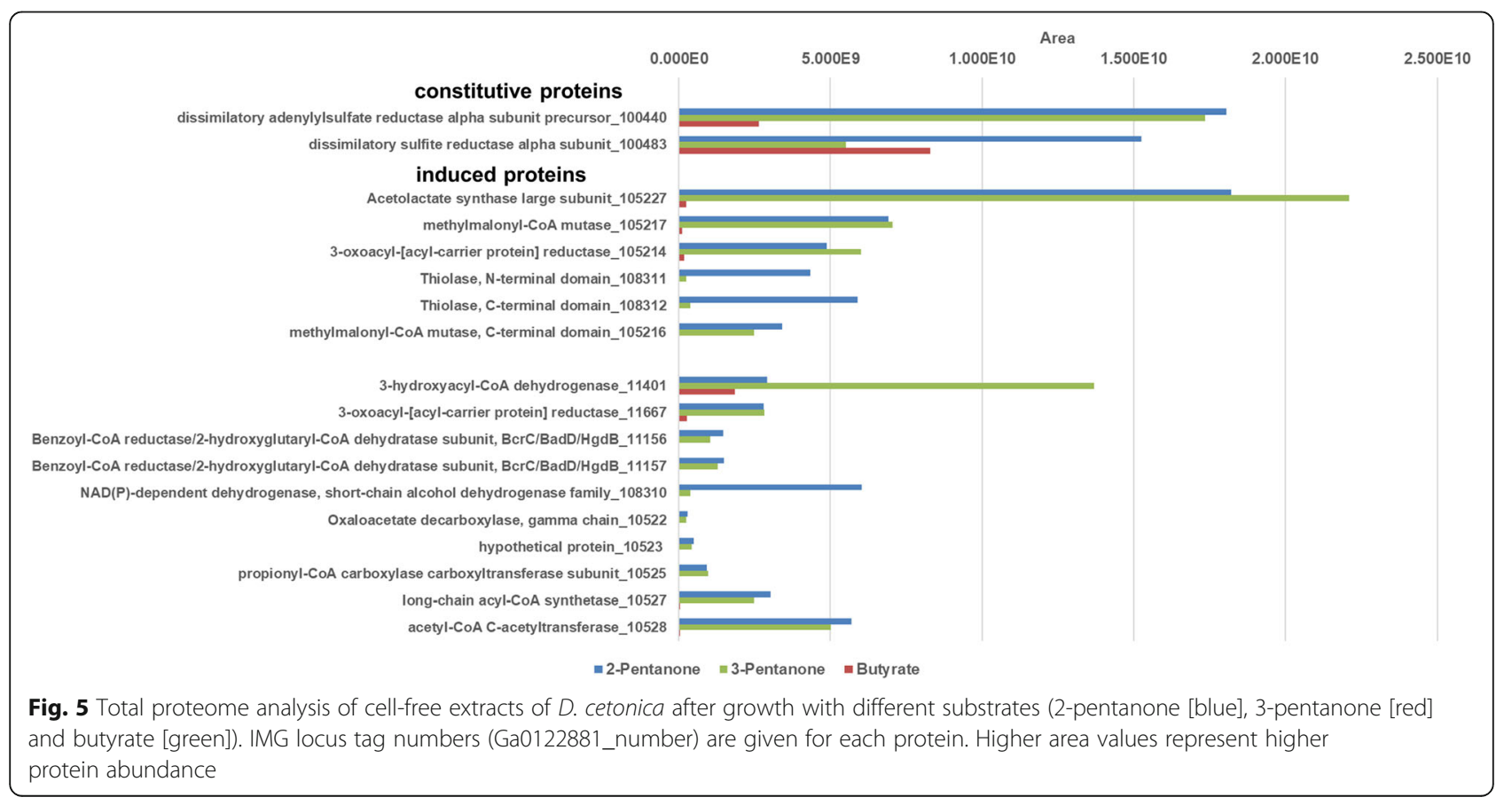


The finding that the same enzyme proteins are highly abundant during growth with acetone, butanone, and isopropanol strongly suggests that degradation of these three substrates involves common proteins.

\section{Differential in vitro activities in cell-free extracts of} isopropanol- and butanone-grown $D$. cetonica Enzyme assays with CFE of isopropanol-grown cells exhibited a specific activity of $35.8 \pm 5.1 \mathrm{mU} \mathrm{mg}^{-1}$ protein for reduction of $5 \mathrm{mM}$ acetone with $0.5 \mathrm{mM} \mathrm{NADH}$, and $14.0 \pm 1.0 \mathrm{mU} \mathrm{mg}^{-1}$ protein for oxidation of $5 \mathrm{mM}$ isopropanol with $5 \mathrm{mM} \mathrm{NAD}^{+}$, whereas no activity (detection limit: $<0.5 \mathrm{mU} \mathrm{mg}^{-1}$ protein) was detected in extracts of butyrate-grown cells. These activities were around 10-fold higher than in acetone- or butanonegrown cells. Activities of NADH-dependent acetone reduction were lower in CFE of acetone- or butanonegrown cells: $3.1 \pm 0.3$ and $4.9 \pm 2.4 \mathrm{mU} \mathrm{mg}^{-1}$ protein, respectively. Enzyme activities of $\mathrm{NAD}^{+}$-dependent isopropanol oxidation were below the detection limit in CFE of acetone- or butanone-grown cells.
$\mathrm{NAD}^{+}$-dependent oxidation of 3-hydroxybutyryl-CoA was detected in isopropanol- and butanone-grown CFEs with specific activities of $250.1 \pm 37.1$ and $391.0 \pm 76.3$ $\mathrm{mU} \mathrm{mg}^{-1}$ protein, respectively. $D$. cetonica grows with isopropanol slower and to lower cell densities than with acetone or butanone [27].

$D$. biacutus has been described as well to grow with butanone and isopropanol [16]. Under both growth conditions, also a $\mathrm{B}_{12}$-dependent isomerization of 2hydroxyisobutyryl-CoA to 3-hydroxybutyryl-CoA was detected using a coupled assay with $\mathrm{NAD}^{+}$. Here, CFE of isopropanol-grown cells of D. cetonica exhibited an activity of $1.8 \pm 0.5 \mathrm{mU} \mathrm{mg}^{-1}$ protein and $1.3 \pm 0.4 \mathrm{mU} \mathrm{mg}^{-1}$ protein for CFE of butanone-grown cells.

Degradation of butanone via initial formylation would lead to a C5-CoA ester, which may be cleaved thiolytically to acetyl-CoA and propionyl-CoA. Propionate is not excreted to the growth medium during growth with butanone, obviously because $D$. cetonica can grow also with propionate as sole carbon source [27]. Degradation pathways in the sulfate-reducing bacteria $D$. biacutus

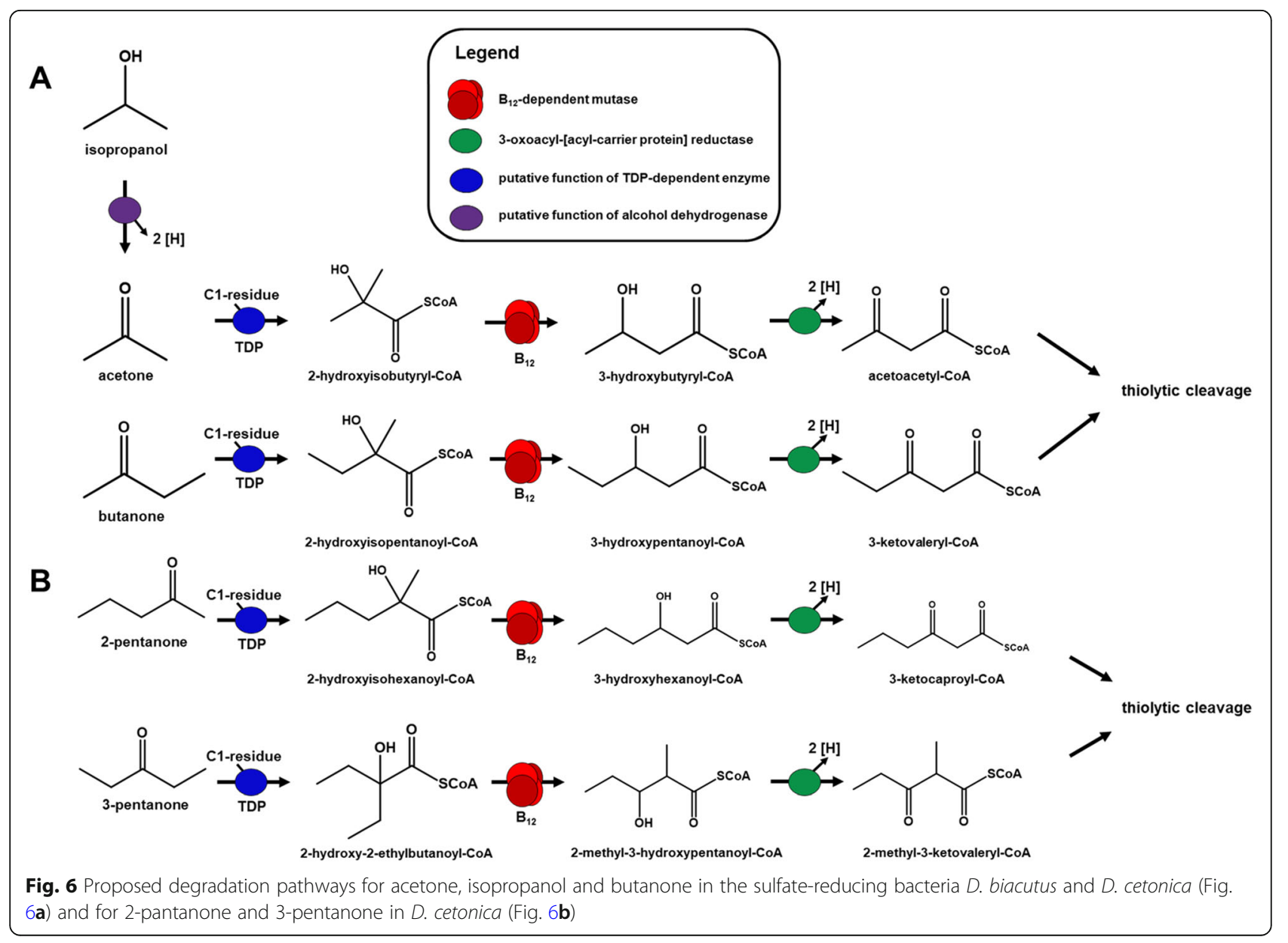


and $D$. cetonica for acetone, isopropanol and butanone are depicted in Fig. 6A. This strategy of activation may be used also for longer ketones and might reflect a common concept for activation and utilization of these ketones.

\section{Proteomic identification of inducible proteins in $D$. cetonica during growth with 2-pentanone and 3- pentanone}

Protein expression patterns after growth with C5compounds like 2-pentanone and 3-pentanone were studied in comparison to butyrate as control substrate. Proteomic analysis was performed with CFEs of 2pentanone- and 3-pentanone-grown cells which had been transferred at least 10 times on the respective substrate. Several induced proteins were identified that exhibited enhanced abundance compared to growth with butyrate (Fig. 5).

One of these most abundant proteins is a TDPdependent acetolactate synthase (105227). Also specifically induced during growth with both pentanones were the small and large subunit $(105,216,105,217)$ of a $B_{12}$ dependent mutase (annotated as methylmalonyl-CoA mutase) and a 3-oxoacyl-[acyl-carrier protein] reductase (105214).

Further proteins with abundance in 2-/3-pentanonegrown cells were identified such as two subunits of a benzoyl-CoA reductase/2-hydroxyglutaryl-CoA dehydratase $(11,156,11,157)$, as well as four proteins whose genes are directly adjacent to each other: a propionylCoA carboxylase carboxyltransferase subunit (10525), an oxaloacetate decarboxylase beta subunit (10524), a hypothetical protein (10523) and an oxaloacetate decarboxylase gamma chain (10522). Also an acetyl-CoA Cacetyltransferase (10528) and a long-chain acyl-CoA synthetase (10527) were identified to be induced during growth with the two pentanones. All of the abovementioned proteins were discovered to be highly abundant also after growth with acetone, butanone and isopropanol.

The results, although still preliminary, indicate that the two pentanones are degraded analogous to acetone and butanone via different intermediates: Pentanone-2 degradation after formylation and linearization would lead to an acetyl and a butyryl residue, whereas degradation of 3-pentanone would form two propionyl-CoA as intermediates (Fig. 6B). It appears that 2-pentanone is easier to degrade than 3pentanone, as 3-pentanone cultures need more than 3 times longer to reach the plateau phase (data not shown). One might speculate that the respective enzymes involved may be sterically hindered by the two ethyl residues of 3-pentanone.

\section{Supplementary Information}

The online version contains supplementary material available at https://doi. org/10.1186/s12866-021-02112-6.

\begin{abstract}
Additional file 1: Figure S1. HPLC-MS chromatograms from lysates of acetone (Sample Acetone 1-3)- and butyrate (Sample Butyrate 1-3)grown cells compared to pure standards of 2-hydroxyisobutyryl-CoA (2$\mathrm{HiB}-\mathrm{CoA}$ ) and 3-hydroxybutyryl-CoA (3-HB-CoA). Acetone-grown cells show substantially more 2-hydroxyisobutyryl-CoA (elutes between 10.30$10.45 \mathrm{~min}$ ) whereas in butyrate-grown cells mainly 3-hydroxybutyryl-CoA (elutes between 10.48-10.58 min) was identified. Figure S2. Gene cluster showing specifically acetone-induced genes in Desulfosarcina cetonica. Most prominent genes are symbolized as red arrows and are annotated as acetolactate synthase (105227), a small and a large subunit of a methylmalonyl-CoA mutase $(105,216,105,217)$ and a 3-oxoacyl-[acyl-carrier protein] reductase (105214). Green genes are found to be expressed acetone-specifically (also in butanone- and isopropanol-grown, not in butyrate-grown (FE) by proteome analysis. These genes are annotated as an oxaloacetate decarboxylase, gamma chain (10522), a hypothetical protein (10523), an oxaloacetate decarboxylase beta subunit (10524), a propionyl-CoA carboxylase carboxyltransferase subunit (10525), a longchain acyl-CoA synthetase (10527), acetyl-CoA C-acetyltransferase (10528), as well as a hydroxymethylglutaryl-CoA lyase (105210), a hypothetical protein (105211), a glyoxylase, beta-lactamase superfamily II (105213), LAO/ AO transport system kinase (105215), an acyl-CoA hydrolase (105218), an anaerobic selenocysteine-containing dehydrogenase (105220), a two component transcriptional regulator, LuxR family (105224) and a histidine kinase-, DNA gyrase B-, and HSP90-like ATPase (105225).
\end{abstract}

\section{Acknowledgements}

We are grateful to Fabian Schneider and Thomas Huhn for the synthesis of reaction compounds. We thank Benjamin Frommeyer and Julia Schmidt for help and technical support, as well as Andreas Marquardt for the proteomic analyses.

\section{Authors' contributions}

J.F. and S.K. did most of the experiments, D.S. helped with the synthesis and analysis of reaction intermediates, M.M. and M.B. ran the experiment for identification of the first reaction intermediate, J.F., D.S. and B.S. wrote the manuscript. The authors read and approved the final manuscript.

\section{Funding}

Research in the Konstanz lab was funded by the Deutsche

Forschungsgemeinschaft (DFG), Bonn, Germany, under grant number Schi 180/16-1. Further financial support came from the universities Freiburg and Konstanz. Open Access funding enabled and organized by Projekt DEAL.

\section{Availability of data and materials}

All supporting data are presented in the main paper and the supplementary files. The genome annotation of Desulfococcus biacutus strain KMRActS and the nucleotide and amino-acid sequences of locus tag DebiaDRAFT_04514 are publicly available within the Joint Genome Institute (JGI) Integrated Microbial Genomes (IMG) system under IMG genome ID 2512047085; the genome sequencing and annotation has been described in ref. [20].

Ethics approval and consent to participate

Not applicable.

\section{Consent for publication}

Not applicable.

\section{Competing interests}

The authors declare that they have no competing interests.

\section{Author details}

${ }^{1}$ Department of Biology, University of Konstanz, 78457 Constance, Germany. ${ }^{2}$ Institute of Biology, Albert-Ludwigs-Universität, Freiburg, 79104 Freiburg, Germany. 
Received: 22 October 2020 Accepted: 29 January 2021

Published online: 16 February 2021

\section{References}

1. Sifniades S, Levy AB, Bahl H: Acetone. In: Ullmann's Encyclopedia of Industrial Chemistry. Wiley-VCH Verlag GmbH \& Co. KGaA; 2011

2. Han B, Gopalan V, Ezeji TC. Acetone production in solventogenic Clostridium species: new insights from non-enzymatic decarboxylation of acetoacetate. Appl Microbiol Biotechnol. 2011;91(3):565-76.

3. Zhao J, Wang Z, Wu T, Wang X, Dai W, Zhang Y, Wang R, Zhang Y, Shi C. Volatile organic compound emissions from straw-amended agricultural soils and their relations to bacterial communities: a laboratory study. J Environ Sci. 2016:45:257-69.

4. Fang J-J, Yang N, Cen D-Y, Shao L-M, He P-J. Odor compounds from different sources of landfill: characterization and source identification. Waste Manag. 2012;32(7):1401-10.

5. Garner CE, Smith S, de Lacy CB, White P, Spencer R, Probert CS, Ratcliffe NM Volatile organic compounds from feces and their potential for diagnosis of gastrointestinal disease. FASEB J. 2007;21(8):1675-88.

6. Kalapos MP: On the mammalian acetone metabolism: from chemistry to clinical implications. Biochimica et Biophysica Acta (BBA)-General Subjects 2003, 1621(2):122-139.

7. de Gouw JA, Howard CJ, Custer TG, Fall R. Emissions of volatile organic compounds from cut grass and clover are enhanced during the drying process. Geophys Res Lett. 1999;26(7):811-4.

8. Mopper K, Stahovec WL. Sources and sinks of low molecular weight organic carbonyl compounds in seawater. Mar Chem. 1986;19(4):305-21.

9. Kotani T, Yurimoto $H$, Kato N, Sakai Y. Novel acetone metabolism in a propane-utilizing bacterium, Gordonia sp. strain TY-5. J Bacteriol. 2007;189(3): 886-93.

10. Hausinger RP. New insights into acetone metabolism. J Bacteriol. 2007; 189(3):671-3.

11. Heider J, Schühle K, Frey J, Schink B. Activation of acetone and other simple ketones in anaerobic bacteria. J Mol Microbiol Biotechnol. 2016; 26(1-3):152-64.

12. Schühle $K$, Heider J. Acetone and butanone metabolism of the denitrifying bacterium "Aromatoleum aromaticum" demonstrates novel biochemical properties of an ATP-dependent aliphatic ketone carboxylase. J Bacteriol. 2012:194(1):131-41.

13. Platen $H$, Schink B. Anaerobic degradation of acetone and higher ketones via carboxylation by newly isolated denitrifying bacteria. J Gen Microbiol. 1989;135(4):883-91.

14. Platen $H$, Schink $B$. Enzymes involved in anaerobic degradation of acetone by a denitrifying bacterium. Biodegradation. 1990;1 (4):243-51.

15. Madigan MT. Photocatabolism of acetone by nonsulfur purple bacteria. FEMS Microbiol Lett. 1990;71(3):281-5.

16. Platen $\mathrm{H}$, Temmes $\mathrm{A}$, Schink $\mathrm{B}$. Anaerobic degradation of acetone by Desulfococcus biacutus spec. Nov. Arch Microbiol. 1990;154(4):355-61.

17. Oosterkamp MJ, Boeren S, Atashgahi S, Plugge CM, Schaap PJ, Stams AJ: Proteomic analysis of nitrate-dependent acetone degradation by Alicycliphilus denitrificans strain BC. FEMS microbiology letters 2015, 362(11): fnv080.

18. Platen $\mathrm{H}$, Schink $B$. Methanogenic degradation of acetone by an enrichment culture. Arch Microbiol. 1987;149(2):136-41.

19. Muyzer G, Stams AJ. The ecology and biotechnology of sulphate-reducing bacteria. Nat Rev Microbiol. 2008:6(6):441-54.

20. Kováč J, Vítězová M, Kushkevych I. Metabolic activity of sulfate-reducing bacteria from rodents with colitis. Open Medicine. 2018:13(1):344-9.

21. Kushkevych I, Castro Sangrador J, Dordević D, Rozehnalová M, Černý M, Fafula R, Vítězová M, Rittmann SK-M. Evaluation of physiological parameters of intestinal sulfate-reducing bacteria isolated from patients suffering from IBD and healthy people. J Clin Med. 2020;9(6):1920.

22. Kushkevych I, Dordević D, Vítězová M. Toxicity of hydrogen sulfide toward sulfate-reducing bacteria Desulfovibrio piger Vib-7. Arch Microbiol. 2019; 201(3):389-97.

23. Cummings J, Macfarlane G, Macfarlane $\mathrm{S}$. Intestinal bacteria and ulcerative colitis. Current issues in intestinal microbiology. 2003:4(1):9-20.

24. Kushkevych I, Cejnar J, Treml J, Dordević D, Kollar P, Vítězová M. Recent advances in metabolic pathways of sulfate reduction in intestinal Bacteria. Cells. 2020;9(3):698.
25. Janssen PH, Schink B. Metabolic pathways and energetics of the acetoneoxidizing, sulfate-reducing bacterium. Desulfobacterium cetonicum Archives of Microbiology. 1995;163(3):188-94.

26. Janssen PH, Schink B. Catabolic and anabolic enzyme activities and energetics of acetone metabolism of the sulfate-reducing bacterium Desulfococcus biacutus. J Bacteriol. 1995;177(2):277-82.

27. Galushko A, Rozanova E: Desulfobacterium cetonicum spec. nov., a sulfatereducing bacterium oxidizing fatty acids and ketones. Microbiology (Moscow, Russ Fed) 1991, 60:102-107.

28. Gutiérrez Acosta OB, Schleheck D, Schink B: Acetone utilization by sulfatereducing bacteria: draft genome sequence of Desulfococcus biacutus and a proteomic survey of acetone-inducible proteins. BMC genomics 2014, 15 (1)(584)

29. Gutiérrez Acosta OB, Hardt N, Schink B. Carbonylation as a key reaction in anaerobic acetone activation by Desulfococcus biacutus. Appl Environ Microbiol. 2013;79(20):6228-35.

30. Frey J, Schneider F, Huhn T, Spiteller D, Schink B, Schleheck D. Two enzymes of the acetone degradation pathway of Desulfococcus biacutus: coenzyme $B_{12}$-dependent 2-hydroxyisobutyryl-CoA mutase and 3hydroxybutyryl-CoA dehydrogenase. Environ Microbiol Rep. 2018;10(3): 283-92.

31. Schmidt A, Müller N, Schink B, Schleheck D. A proteomic view at the biochemistry of syntrophic butyrate oxidation in Syntrophomonas wolfei. PLoS One. 2013;8(2):e56905.

32. Neuhoff V, Arold N, Taube D, Ehrhardt W. Improved staining of proteins in polyacrylamide gels including isoelectric focusing gels with clear background at nanogram sensitivity using Coomassie brilliant blue G-250 and R-250. Electrophoresis. 1988;9(6):255-62.

33. Keller A, Schink B, Müller N. Alternative pathways of Acetogenic ethanol and methanol degradation in the Thermophilic anaerobe Thermacetogenium phaeum. Front Microbiol. 2019:10:423

34. Rabinowitz JD, Kimball E. Acidic acetonitrile for cellular metabolome extraction from Escherichia coli. Anal Chem. 2007:79(16):6167-73.

35. Korotkova N, Lidstrom ME. MeaB is a component of the methylmalonyl-CoA mutase complex required for protection of the enzyme from inactivation. J Biol Chem. 2004;279(14):13652-8.

36. Frey J, Rusche H, Schink B, Schleheck D. Cloning, functional expression and characterization of a bifunctional 3-hydroxybutanal dehydrogenase /reductase involved in acetone metabolism by Desulfococcus biacutus. BMC Microbiol. 2016;16(1):280.

\section{Publisher's Note}

Springer Nature remains neutral with regard to jurisdictional claims in published maps and institutional affiliations.
Ready to submit your research? Choose BMC and benefit from:

- fast, convenient online submission

- thorough peer review by experienced researchers in your field

- rapid publication on acceptance

- support for research data, including large and complex data types

- gold Open Access which fosters wider collaboration and increased citations

- maximum visibility for your research: over $100 \mathrm{M}$ website views per year

At BMC, research is always in progress.

Learn more biomedcentral.com/submissions 